\title{
Fungsi Bahasa Indonesia dan Fungsi Teks dalam Pembelajaran Bahasa Indonesia
}

\section{Chindi Oktiani Nofa}

\section{Email : chindinofa@gmail.com}

Menurut Chaer (dalam Diah \& Wulandari, 2015), Fungsi bahasa sebagai alat komunikasi manusia mencakup lima fungsi dasar, yaitu fungsi ekspresi, fungsi informasi, fungsi eksplorasi, fungsi persuasi dan fungsi entertainmen. Fungsi ekspresi mewadahi konsep bahwa bahasa merupakan media manusia untuk melahirkan ungkapan-ungkapan batin yang ingin disampaikan penutur kepada orang lain. Fungsi informasi adalah fungsi untuk menyampaikan pesan atau amanat kepada orang lain. Fungsi eksplorasi adalah penggunaan bahasa untuk menjelaskan suatu hal, perkara dan keadaan. Fungsi persuasi merupakan penggunaan bahasa yang bersifat mengajak atau mempengaruhi. Sedang fungsi entertainmen bahasa adalah penggunaan bahasa untuk menghibur, menyenangkan dan memuaskan batin. Kelima fungsi ini sangat mendukung proses pengembangan ilmu pengetahuan, terutama fungsi informasi dan fungsi eksplorasi. Menurut Dardjowidjoyo (dalam Diah \& Wulandari, 2015) kemampuan berbahasa merupakan ciri khusus manusia, bahkan sebelum manusia bisa bicara ia sudah bisa berbahasa sesuai dengan pendapat Kridalaksana (dalam Suardi et al, 2019) bahasa merupakan alat komunikasi yang diperoleh manusia sejak lahir. Menurut Astuti et al (2012), bahasa pada prinsipnya merupakan alat untuk berkomunikasi dan alat untuk menunjukkan identitas masyarakat pemakai bahasa. Bahasa hidup dan berkembang dalam suatu masyarakat dan dipakai oleh warganya untuk berkomunikasi. Kesantunan berbahasa merupakan keterampilan yang harus dimiliki oleh setiap manusia guna berinteraksi dan berkomunikasi dengan orang lain. Keterampilan berbahasa tersebut menjadi bagian yang sangat penting bagi setiap orang agar dapat mengemukakan pikiran dan perasaannya secara baik dan menyeluruh. 
Agustina (1995:15) menyebutkan, "konteks adalah dalam kebudayaan mana dan suasana apa serta siapa saja yang terlibat dalam kegiatan berbahasa itu." Di dalam pragmatik, konteks berarti semua latar belakang pengetahuan yang dipahami bersama oleh penutur dan mitra tuturnya. Konteks itu berperan membantu mitra tutur dalam menafsirkan maksud yang akan disampaikan oleh penutur. Pembelajaran tidak berhasil jika tidak terdapat respon siswa. Mulyadi (2007: 260) menyatakan, "respon verbal adalah usaha-usaha yang dilakukan secara sadar untuk berhubungan dengan orang lain secara lisan." Suatu sistem verbal disebut bahasa. Bahasa verbal adalah sarana utama untuk menyatakan pikiran, perasaan, dan maksud kita. Bahasa verbal menggunakan kata-kata yang merepresentasikan berbagai aspek realitas individu kita. Respon nonverba adalah semua isyarat yang bukan kata-kata (Mulyadi, 2007:343). Selain itu, Harvey dan Smith (dalam Ahmadi, 1992:166) membagi respon menjadi dua bagian, yaitu (a) Respon positif, yaitu sebuah bentuk respon, tindakan, atau sikap yang menunjukkan atau memperlihatkan, menerima, mengakui, menyetujui, dan melaksanakan norma-norma yang berlaku di mana individu itu berada. (b) Respon negatif, yaitu bentuk respon, tindakan, atau sikap yang menunjukkan atau mempertihatkan penolakan atau tidak menyetujui terhadap norma-norma yang berlaku di mana individu itu berada.

Dari hasil penelitian tentang fungsi bahasa Indonesia sebagai alat komunikasi dalam kehidupan sehari-hari. Teks biografi memberikan wawasan kepada seseorang tentang tokoh seseorang seperti Soekarno sangat setuju $42,9 \%$, tidak setuju $57,1 \%$. Pembelajaran teks laporan hasil observasi dengan media video pengetahuan membuat minat belajar siswa meningkat sangat setuju $35,7 \%$, tidak setuju $64,3 \%$. Siswa harus mengerti dalam memilih teks yang tepat untuk materi pembelajaran bahasa Indonesia sangat setuju 60,7\%, tidak setuju35,7\%. Siswa harus mempelajari salah satu teks dan harus bisa mempelajari dalam bidang teks yang dipilihnya sangat setuju $42,9 \%$, tidak setuju $57,1 \%$. Teks eksplonasi banyak disenangi peserta didik dalam pembelajaran bahasa Indonesia sangat setuju $71,1 \%$, tidak setuju $35,7 \%$. Pengaruh bahasa gaul dihapuskan demi melestarikan bahasa Indonesia sangat setuju $71,6 \%$, tidak setuju $28,6 \%$. Bahasa Indonesia sangat mudah diajarkan dalam membuat teks tentang pembelajaran bahasa Indonesia sangat setuju 7,1\%, tidak setuju28,6\%. Fungsi bahasa 
Indonesia sebagai bahasa pemersatu bangsa sangat setuju $25 \%$, tidak setuju $75 \%$. Teks deskripsi dibuat untuk peraturan dalam peserta didik sangat setuju 42,9\%, dan tidak setuju57,1\%. Fungsi utama bahasa untuk mempelajari berbagai sejarah bahasa Indonesia sangat setuju $71,1 \%$, tidak setuju $39,3 \%$.

Dalam kehidupan sehari-hari kita selalu menggunakan bahasa untuk berkomunikasi dengan orang lain. Begitu dekatnya kita dengan bahasa terutama bahasa Indonesia yang menjadi bahasa utama di negara kita. Banyak orang beranggapan karena terlalu sering kita menggunakan bahasa Indonesia kita tidak perlu mempelajari bahasa Indonesia. Akibatnya, banyak masyarakat sebagai pemakai bahasa tidak terampil menggunakan bahasa Indonesia dalam pengucapan kata-kata atau pemakaian kata dalam berkomunikasi. Banyak orang beranggapan fungsi bahasa Indonesia hanya sebagai alat komunikasi. Namun, pada dasarnya bahasa Indonesia memiliki banyak fungsi yang digunakan berdasarkan kebutuhan seseorang, yakni sebagai alat untuk mengekspresikan diri, sebagai alat untuk berkomunikasi, sebagai lambang kebanggaan, sebagai bahasa pengantar dalam pendidikan, sebagai alat untuk mengadakan integrasi dan beradaptasi sosial dalam lingkungan atau situasi tertentu, dan alat pemersatu suku budaya dan bahasanya.Bahasa juga diperlukan dalam membuat suatu teks,baik teks argumentasi, teks cerpen, teks biografi dan teks puisi. Dari keempat macam teks tersebut memiliki kegunaannya masing-masing.

Banyak caranya orang bernggapan fungsi teks bisa diekspresikan langsung ke murid bahkan ke guru. Berdasarkan penelitian penulis Teks biografi memberikan wawasan kepada seseorang tentang tokoh seseorang seperti Soekarno sangat setuju 42,9\%, tidak setuju 57,1\%. Pembelajaran teks laporan hasil observasi dengan media video pengetahuan membuat minat belajar siswa meningkat sangat setuju $35,7 \%$, tidak setuju $64,3 \%$. Siswa harus mengerti dalam memilih teks yang tepat untuk materi pembelajaran bahasa Indonesia sangat setuju $60,7 \%$, tidak setuju35,7\%. Siswa harus mempelajari salah satu teks dan harus bisa mempelajari dalam bidang teks yang dipilihnya sangat setuju $42,9 \%$, tidak setuju $57,1 \%$. Teks eksplonasi banyak disenangi peserta didik dalam pembelajaran bahasa Indonesia sangat setuju $71,1 \%$, tidak setuju $35,7 \%$. Pengaruh bahasa gaul dihapuskan demi melestarikan bahasa Indonesia sangat 
setuju $71,6 \%$, tidak setuju $28,6 \%$. Bahasa Indonesia sangat mudah diajarkan dalam membuat teks tentang pembelajaran bahasa Indonesia sangat setuju 7,1\%, tidak setuju28,6\%. Fungsi bahasa Indonesia sebagai bahasa pemersatu bangsa sangat setuju $25 \%$, tidak setuju $75 \%$. Teks deskripsi dibuat untuk peraturan dalam peserta didik sangat setuju 42,9\%, dan tidak setuju57,1\%. Fungsi utama bahasa untuk mempelajari berbagai sejarah bahasa Indonesia sangat setuju $71,1 \%$, tidak setuju $39,3 \%$. Fungsi sosial cerita rakyat ini dipertegas lagi oleh Hasanuddin WS (dalam Amin, I,. \& Syahrul $R$, 2013) yang menguraikan bahwa fungsi sosial cerita rakyat bagi kehidupan dalam masyarakat adalah untuk mengembangkan integritas masyarakat, alat kontrol sosial, memadukan kekuatan kebersamaan yang terpecah untuk solidaritas sosial, identitas kelompok, dan harmonisasi komunal. Bahasa juga berfungsi sebagai alat berkomunikasi antara anggota masyarakat. Fungsi tersebut digunakan dalam berbagai lingkungan, tingkatan, dan kepentingan yang beraneka ragam, misalnya: komunikasi ilmiah, komunikasi bisnis, komunikasi kerja, dan komunikasi sosial, dan komunikasi budaya (Susilo, 2014).

Berdasarkan hasil penelitian yang dibuat oleh penulis berdasarkan angket yang telah disebar dapat disimpulkan fungsi bahasa Indonesia bisa digunakan dalam semua teks, teks dalam fungsi bahasa ada banyak contohnya teks eksposisi yang menjadi pedoman pembelajaran bahasa Indonesia yang saat ini diterapkan merupakan contoh dari salah fungsi bahasa dalam pembelajaran bahasa Indonesia saat ini. Tidak hanya itu kita bisa mengetahui sejarah, perkembangan fungsi bahasa Indonesia jika kita menerapkannya dalam lingkungan sekolah. Teks dalam fungsi bahasa Indonesia sangat berpengaruh dalam mempelajrai cinta dan fungsi bahasa Indonesia didalam pembelajaran bahasa Indonesia. 


\section{DAFTAR RUJUKAN}

Agustina. (1995). Pragmatik dalam Pengajaran Bahasa Indonsia. Padang: FBSS

IKIP Padang

Amin, I,. Syahrul R, E. (2013). CERITA RAKYAT PENAMAAN DESA DI KERINCI:

Kategori dan Fungsi Sosial Teks. Journal of Chemical Information and Modeling, 1(1). https://doi.org/10.1017/CBO9781107415324.004

Astuti, R., \& Syahrul, R. (2012). Kesantunan berbahasa dalam talkshow "neo democrazy di metro tv. Jurnal Pendidikan Bahasa Dan Sastra Indonesia, 1(1).

Diah, K., \& Wulandari, A. (2015). Peranan Bahasa dalam Pengembangan IImu Pengetahuan.

Gusnita, R., Ramadhan, S., \& Gani, E. (2012). Hubungan Kemampuan Berpikir Logis

Dengan Kemampuan Menulis Karangan Argumen Siswa Kelas X SMA. Jurnal Pendidikan

Bahasa Dan Sastra Indonesia, 1.

Jimat Susilo. (2014). Peran dan Fungsi Bahasa Indonesia. Jurnal Logika.

Suardi, I. P., Ramadhan, S., \& Asri, Y. (2019). Pemerolehan Bahasa Pertama pada Anak Usia Dini. Jurnal Obsesi : Jurnal Pendidikan Anak Usia Dini, 3(1), 265. https://doi.org/10.31004/obsesi.v3i1.160 
Syahrul R. (2008). Pragmatik Kesantunan Berbahasa. Padang: UNP Press.

Mulyadi, Deddy. (2007). IImu Komunikasi. Bandung: Remaja Rosdakarya. 